\title{
Optimális erőforrás-allokáció a kék gazdaság vállalatainál*
}

\author{
Hartung Katalin
}

A cikk a környezetterhelés minimalizálására törekvő vállalatok optimális erőforrás-allokációját és belső elszámolóárainak meghatározását modellezi. A szerző a lineáris tevékenységelemzési modell segitségével definiálja a nullahulladék-elv, más néven a kék gazdaság fogalmát. Megmutatja, hogy amennyiben nincs technológiai lehetőség a nullahulladék-elv betartására, akkor a vállalat csak a környezet terhelése révén érhet el nyereséget. Megmutatja azt is, hogy a melléktermék belső elszámolóára hogyan számszerüsithető, és miként vehet fel egyaránt negativ és pozitiv értéket, elösegítve ezzel a kék gazdaság célkitüzést követő piaci nyitottságot. Megmutatja végül azt is, hogy a kibocsátási korlátokhoz tartozó árnyékárak a szennyezéstől visszatartó környezetvédelmi bírságolás alapjául szolgálhatnak.

Journal of Economic Literature (JEL) kódok: C65, Q56

Kulcsszavak: belső elszámolóár, erőforrás-allokáció, környezetterhelés, nullahulladék elv, környezetvédelmi bírság

\section{Bevezetés}

Ghisellinia et al. (2016), valamint Munck - Scheel (2016) szerint alapvetően fontos célkitǔzés, hogy a gazdasági növekedést alacsonyabb környezetterhelés kísérje. Ebből következően olyan termelési technológiáknak kell előtérbe kerülniük, melyek minimális káros következménnyel járnak a környezetre és az emberi egészségre, miközben lehetőség szerint a teljes kibocsátás hasznosul a vállalat nyereséges múködése során. Jaehn (2016) tanulmányában rávilágított, hogy a növekedéssel járó negatív környezeti kihívások kezelésére - mindössze tíz-húsz évvel ezelött megjelent a fenntartható termelés fogalma, mely alatt az erőforrás-hatékonyságot támogató irányzatokat érti.

\footnotetext{
* Jelen cikk a szerző nézeteit tartalmazza, és nem feltétlenül tükrözi a Magyar Nemzeti Bank hivatalos álláspontját.
}

Hartung Katalin a Pécsi Tudományegyetem Közgazdaságtudományi Karának tudományos munkatársa. Email: hartungk@ktk.pte.hu.

Köszönettel tartozom Bessenyei Istvánnak, a Pécsi Tudományegyetem Közgazdaságtudományi Kar egyetemi docensének a közös kutatásunkban nyújtott szakmai segítségéért.

A magyar nyelvű kézirat első változata 2016. december 19-én érkezett szerkesztőségünkbe.

DOI: http://doi.org/10.25201/HSZ.16.3.98118 
Az elmúlt időszakban az új fenntartható fejlődési irányzatok vállalati szintú alkalmazása egyre gyakoribb. Az irányzatok közül cikkünkben a nullahulladék-elv követésére törekvő kék gazdaság (Bocken et al. 2014; Pauli 1998) múködését tárgyaljuk részletesen. A kék gazdaság alapelveit bizonyos fokig megfogalmazták már létező elméletek, például az ipari ökológia (Esty - Porter 1988), a nullahulladék-elv (Pauli 1997), illetve a biomimikri (Benyus 2002). Ennek ellenére a kék gazdaság határozottan újnak mondható jellemzője, hogy az egész gazdaságot az ökológiai rendszerekkel összhangban képzeli el (Pauli 2010). A holisztikus megközelítés - eredeti értelmezése szerint - abból indul ki, hogy minden vállalat összefüggésben áll a környezetével, így egy adott gazdasági rendszert a környezetével együtt lehet igazán a maga teljességében vizsgálni. Ezzel a szemléletmóddal ismerhetünk meg egy adott gazdasági rendszert, illetve annak elemeit. Ezt az alapelvet a biomimikri követi, leginkább termékszinten. A többi elmélet eredetileg nem holisztikus (erre általában utal az elnevezésük is). Általában mindegyik fenntartható fejlődés irányzatra igaz, hogy körforgásos mintákban gondolkoznak, csökkentve az ásványi nyersanyag- és eröforrás-készletek felhasználását, illetve a vállalat indirekt környezetterhelését. A kék gazdaság szemléletmódja szerint a vállalatok erőforrásként tekintenek a hulladékra, egyfajta választ adva a környezeti problémák kezelésére. Ezen hulladékok helyettesítik a termelő vállalatok erőforrás- szükségletét vagy annak egy részét, míg csökkentik a költségeket vagy többletbevételt eredményeznek. Hartung (2016) irodalmi áttekintéséből kitűnik, hogy a kék gazdaság fogalmának egzakt meghatározásával a szakirodalom mindmáig adós maradt, továbbá nem tisztázott a termelés során felhasznált melléktermékek belső elszámolóárainak optimális kialakítása sem. A kék gazdaságnak vannak vállalatszintű alkalmazásai is, illetve erőforrás-hatékonyságának köszönhetően a kék gazdaság elveit követő vállalatok gyakran alakítanak ki vállalaton belüli vagy vállalatközi szinergikus együttmúködéseket, hogy hatékonyabb körforgásos struktúrát hozzanak létre. Ghisellinia et al. (2016) szerint a kék gazdaság elvei szerint múködő vállalat stratégiája a tisztább termelés és az ökológiai szemléletű tervezés. Khalili et al. (2015) és Ghisellinia et al. (2016) rámutattak, hogy a tisztább termelés alapvetően erőforrás-hatékonysággal bír. A hulladék- és károsanyag-kibocsátás csökkentésével foglalkozik a termék- és folyamattervezés vállalatszintű alkalmazása során. Támogatja az integrált és preventív környezeti stratégiákat, hogy egyensúlyt teremtsen a vállalat és a környezet között. Klemes et al. (2012) alátámasztja, hogy a tisztább termelés egyre fontosabb eszköz lesz valamennyi ipari szereplő számára. Genovese et al. (2015) tapasztalatai szerint a vállalatok egyre nagyobb hangsúlyt fektetnek a csővégi megoldásokon túl arra, hogy a teljes termék vagy szolgáltatás életciklusa során figyelemmel kísérjék és javítsák a gazdaságra, a környezetre és a társadalomra gyakorolt hatását. Li - Su (2012) kutatása szerint a körforgásos gazdaság a természeti erőforrások hatékonyabb kihasználásával törekszik az ember és a természet egyensúlyának fenntartására. Ezen túl a körforgásos gazdaság termelési folyamatokat határoz meg. Ez alatt azt értjük, hogy a vállalat zárt rendszerben múködik, ahol a rendszerben tartott hulladék helyettesíti az eset- 
leges ásványinyersanyag- vagy természetierőforrás-szükségletet. Li és Su (2012) azt tapasztalta, hogy a körforgásos gazdaságot alkalmazó vállalatok jellemzően alacsonyabb kezdeti beruházási költséggel rendelkeztek, a termelés során minimalizálták az ipariszennyezőanyag-kibocsátást, a rendelkezésre álló készleteket maximálisan kihasználták és a környezetre a lehető legkisebb negatív hatást gyakorolták. Pauli (1998) munkájában arra hívja fel a figyelmet, hogy egy vállalat önmagában képtelen a nullahulladék-elv betartására, ezért a melléktermékek vállalatok közti adásvételét nélkülözhetetlennek tartja. A kék gazdaság elvének fontos eleme tehát a vállalatok közti együttmúködés, melynek célja az egyik vállalat termelése során keletkezett melléktermék alapanyagként, félkész termékként vagy segédanyagként történő felhasználása egy másik vállalat termelési folyamatában.

A vállalatok esetében korántsem szabályozott a vállalaton belül újra felhasznált vagy kapcsolt vállalkozáson keresztül vásárolt melléktermékek (félkész termékek, hulladékok vagy szennyezőanyagok) értékelése. Ezen ügyletek belső elszámolóáron, úgynevezett transzferáron kerülnek értékesítésre, mely árak hatással vannak a vállalat költségeire és nyereségére. Érezhető, hogy a belső elszámolóárakat nem a kereslet és a kínálat törvénye határozza meg, hanem nagyobbrészt a fizetendő adók, adójellegű költségvetési befizetések és vámok minimalizálásának szándéka (Gao - Zhao 2015). Nemzetközileg egy, az OECD által készített tanulmány ${ }^{1}$ ad iránymutatást a vállalatoknak a belső elszámolóárak kialakításával kapcsolatban, míg Magyarországon a társasági adóról és osztalékadóról szóló 1996. évi LXXXI. törvény foglalkozik a vállalatcsoporton belül alkalmazott transzferár és a független felek között alkalmazott szokásos piaci ártól eltérő árak alkalmazása során felmerült adóalap-kiigazítás szabályaival. Ding et al. (2015) megvizsgálták, mi történik, ha a vállalatok környezetre gyakorolt negatív hatásukból (input és output) fakadó költségei megjelennek a könyvelésben. Kutatásukban a fenntartható ellátási láncok optimális árképzését vizsgálták kvantitatív módszerekkel, azaz a környezeti externáliákat igyekeztek internalizálni. Megvizsgálták az eltérő árképzési lehetőségek (decentralizált, centralizált vagy részlegek között meghatározott árképzési lehetőségek) változását, továbbá az ellátási lánc szereplőit befolyásoló hajtóerőket, végül az állam által használt vállalati ösztönzők szerepét. A szerzők megállapították, hogy a szakirodalom alig ír olyan irányú együttmúködésről, mely a fenntartható ellátási lánc szereplőit motiválná a szennyezőanyagokat csökkentő beruházási döntések, illetve a melléktermékek (pl. szennyezők) vállalatok közti adásvételére. Lakatos Karai (2015) cikkében arra kereste a választ, hogy a szén-dioxid-kvóták beszerzésére és eladására milyen hatással van a piaci ár alakulása, a magyar számviteli törvény sajátossága és a kapcsolt vállalati viszony megléte. Szakirodalmi áttekintőjükből kiderül, hogy a kibocsátási egységek számviteli besorolása megválaszolásra került, ám kereskedelmének társasági adózása és az ehhez kapcsolódó transzferárazási

\footnotetext{
${ }^{1}$ Transfer Pricing Guidelines for Multinational Enterprises and Tax Administrations. OECD, 2010, ISBN 97892-64-09018-7.
} 
problémák feltáratlan területek maradtak. Megállapításuk szerint a szén-dioxid-kvóta elszámoló árazása sem mentesül a piaci ár alkalmazásának kötelezettségétól. Amennyiben a kapcsolt vállalatok eltérnek a piaci árazástól, társaságiadó-alapjukat kell annak megfelelően korrigálni. Kuti (2014) szerint nincs mindig mód a társadalmi és környezeti externáliák pénzügyi jelentőségének befektetési célú kvantifikálására, másrészt a hosszú távú költségek és hatások diszkontálása miatt elhanyagolhatóvá válnak ezek az externáliák. Az utóbbi állítással nem értünk egyet, mert a vállalatok természeti környezetre gyakorolt hatása véleményünk szerint hosszú távon is számottevő.

A szennyező vállalatokra kiszabott környezetvédelmi bírság szakirodalma is még kiforratlan. Karpoff et al. (1998) szerint a kirótt környezetszennyezési bírságok nincsenek összefüggésben a szennyezés mértékével. Tapasztalataik szerint azok alakulása változékony és kiszámíthatatlan. A piaci részvények szennyezés miatti árfolyamcsökkenése és a kiszabott bírság nagysága között azonban sikerült összefüggést kimutatni. Az OECD (2009) tanulmánya a kelet-európai, kaukázusi és közép-ázsiai országok környezetszennyezési bírságolásának szabályait vizsgálja. Kitúnik, hogy a szabályozás számos helyen hiányos. Gyakran olyan alapfogalmak jelentése tisztázatlan, mint a környezetvédelmi bírság, -díj és -kár vagy kompenzáció. Ugyanakkor az OECD (2009) tanulmányában említett országoknál hasonlóságot látunk Németországgal a bírságot enyhítő körülmény tekintetében. Ha az elkövető vállalat környezetvédelmi tevékenységet folytatott korábban - ám a környezetszennyezés mégis bekövetkezett - akkor a kiszabott bírság mértéke csökken (Schelmminger - Martens 2004). A bírság nagysága azonban országonként eltérő. A kelet-európai és a kaukázusi országokban a megengedett határérték fölött történő kibocsátás esetén kiszabott bírság függ a kibocsátott szennyezőanyag mennyiségétől és veszélyességétől. Kazahsztánban a vállalat által okozott környezetszennyezés után járó bírságot kizárólag az okozott kár mértéke határozza meg. Ezzel szemben Németországban a büntetőjog pénzügyi bírságot és/vagy börtönbüntetést is elrendelhet (Schelmminger - Martens 2004).

Az imént említett irodalmi hiányosságok miatt jelen tanulmány célja a környezetre gyakorolt negatív hatásokat minimalizáló vállalati modell felhasználásával a kék gazdaság vállalatának definíciója, a melléktermékek (szennyezőanyagok) belső elszámolóárainak meghatározása és javaslattétel a környezetvédelmi bírság mértékére. Ehhez a továbbiakban a Bessenyei (2016) cikkében alkalmazott lineáris tevékenységelemzési modellt használjuk. A lineáris tevékenységelemzési modellt (LTM) optimális erőforrás-allokációs problémákhoz használják, ami lehetővé teszi a választást a technológiák között, valamint az ikertermelést (Zalai 2012). Az ikertermelés jelentősége a melléktermék- és szennyezőanyag-kibocsátások modellben való megjelenítésekor jelentkezik, hiszen az LTM-modell képes feltüntetni a vállalatok termelése során keletkezett és felhasznált köztes és melléktermékek áramlását is. A kék gazdaságban a technológiai választék megjelenítése elengedhetetlen, 
hiszen az egyes technológiák eltérő módon szennyezik a környezetet. A lineáris tevékenységelemzés modellje a különféle szennyezőanyagok kibocsátását egymástól elkülönítetten kezeli, így lehetőség nyílik annak figyelembe vételére, hogy az egyik technológia az „A" típusú szennyezőanyagból bocsát ki többet, míg a másik technológia a „B” típusúból. Más, bonyolultabb modellek is alkalmasak a probléma felírására, de azok a jelen cikk keretein túlmutatnak. Feltételezzük továbbá Pauli (1998) imént említett megjegyzése nyomán a piaci és a technológiai nyitottságot, ahol a környezetvédelmi stratégia szempontjai is központi szerepet kapnak.

A tanulmány második szakasza röviden bemutatja az LTM módszertanát. A harmadik szakasz ismerteti a környezetkímélő stratégia, azaz a kék gazdaság elv vállalati alkalmazását a lineáris tevékenységelemzési modell módszertani keretei között. Ebben a szakaszban derül ki az árnyékár és a belső elszámolóár közti kapcsolat, illetve meghatározásra kerül a környezetvédelmi bírság kiszabásának alapja. A negyedik szakasz bemutatja a kék gazdaság elveit követni képtelen, de minimális környezetterhelésre törekvő kvázi kék gazdaság típusú vállalat múködését LTM-környezetben. Végül a tanulmányt a jövőbeli kutatási irányok és a következtetések zárják.

\section{Módszertan}

A vállalati értékteremtés műszaki és szervezési szempontból lehetséges tevékenységek vagy folyamatok ${ }^{2}$ eltérő intenzitású, azaz eltérő szintǔ alkalmazása révén megy végbe. A lineáris tevékenységelemzési modell eszköze, mint azt korábban említettük, kiválóan alkalmas a melléktermékek különböző tevékenységek közti áramlásának a megjelenítésére, így a későbbiekben a kék gazdaság elv definiálására is. A jelen szakasz tehát röviden bemutatja az LTM-modell alapvető felépítését.

Egy adott termelőtevékenység terméket és/vagy szolgáltatást állít elő. Ennek során a vállalat által elóállított termékeket és szolgáltatásokat használ fel, továbbá a piacon vásárolt erőforrásokat, ilyen például a munka, víz, villamosenergia stb. A továbbiakban az egyszerűség kedvéért a vállalat által előállított szolgáltatásokat is termékeknek nevezzük.

Legyen a vállalatnak $n$-féle terméke, beleértve a félkész termékeket, a hulladékokat, a melléktermékeket és a szolgáltatásokat is. Ezek előállításához használjon fel $N$-féle elsődleges erőforrást! Jelölje $R_{+}$a nemnegatív valós számok halmazát, ekkor egy alaptechnológia a következő három vektor segítségével írható le: $\mathbf{k} \in R_{+}^{n}$ a kibocsátási együtthatók, $\mathrm{r} \in R_{+}^{n}$ ráfordítási együtthatók, $\mathrm{d} \in R_{+}^{n}$ pedig az elsődleges erőforrás felhasználási együtthatók vektora. A három vektor elemei az alaptevékenység egységnyi szintű alkalmazása során szükséges, illetve előállított termék, illetve ráfordítási igényeket adják meg. A szóban forgó tevékenység intenzitása tetszőleges

\footnotetext{
${ }^{2}$ Ezeket a tevékenységeket vagy folyamatokat Zalai (2012) elemi vagy alapeljárásoknak nevezi.
} 
mértékegységben kifejezhető. Ez lehet például a tevékenység üzemeltetési ideje, vagy a tevékenység folytatásához felhasznált valamelyik elsődleges erőforrás (például villamosenergia) mennyisége.

Megjegyzendő, hogy a $\mathbf{k}$ vektornak többnyire egynél több pozitív eleme van, mert a legtöbb folyamat múködése során a további feldolgozásra vagy értékesítésre alkalmas termék mellett melléktermékek, hulladékok, illetve szennyezőanyagok is képződnek. Ha a k vektor minden eleme nulla, akkor a szóban forgó tevékenység célja a szennyezőanyag-mentesítés. Ez azonban ritkán sikerül tökéletesen, ezért szinte mindig van néhány pozitív elem. Ha nincs díjmentes lomtalanítás - vagyis az értékesíthetetlen hulladék- vagy szennyezőanyagok nem tüntethetők el költségmentesen a rendszerből - akkor be kell vezetni az $\mathbf{y}^{\mathbf{p}}$ változót, mely a különféle tevékenységek együttes múködése során keletkezett szennyezőanyagok környezetbe történő kibocsátását írja le, beleértve a hulladékkibocsátást is. Ha a $\mathbf{k}$ vektornak több olyan pozitiv eleme van, mely értékesítésre vagy továbbfeldolgozásra alkalmas termék előállított mennyiségét jelzi, ikertermelésről beszélünk. A vevői igényt az $\mathbf{y} \in R_{+}^{n}$ vektor írja le. Ennek elemei adják meg az egyes termékekből a gyártásvezető számára az előállítandó mennyiségeket. Azon félkész és melléktermékek, segédanyagok, hulladékok és szolgáltatások esetében, melyekre vevői igény nincs, az y vektor megfelelő eleme zérus, bár a vállalat többnyire ezeket is előállítja. Mivel feltételezzük a piaci nyitottságot, a vállalat értékesítheti társvállalatai számára a Kx vektorban található pozitiv elemeket, amelyek mennyiségét a z vektor tartalmazza. Lehetőség nyílik továbbá arra is, hogy a vállalat piacon szerezzen be köztes és félkész termékeket a társvállalatoktól, amennyiben ők hatékonyabban állítják elő azokat. Ezek mennyiségét az u vektor írja le.

Ha az r vektor valamennyi eleme zérus, akkor a szóban forgó alaptevékenység kizárólag elsődleges erőforrásokat használ fel, múködtetéséhez a vállalat által előállított félkész termékekre, segédanyagokra, hulladékokra és szolgáltatásokra nincs szükség. Ritkábban fordul elő, hogy a d vektor áll csupa nullából, mert a legtöbb tevékenység felhasznál valamilyen elsődleges erőforrást.

A legtöbb vállalat természetesen egynél több alaptevékenységet képes folytatni. Ezeket a tevékenységeket az $\underline{\mathbf{x}} \in R_{+}^{m}$ vektor írja le. Legyen a műszaki és a szervezési szempontból rendelkezésre álló tevékenységek száma $m$. Ezek mindegyike leírható az imént bevezetett három vektorral, és így az alábbi mátrixok állíthatók elő:

- Kibocsátási együtthatók mátrixa: $\mathbf{K}=\left(\mathbf{k}_{1}, \mathbf{k}_{2}, \ldots, \mathbf{k}_{\mathbf{m}}\right)$, ahol $\boldsymbol{k}_{i j}$ azt mutatja meg, hogy a j-edik tevékenység egységnyi szintű alkalmazása mennyit állít elő az $i$-edik termékből. 
- Ráfordítási együtthatók mátrixa: $\mathbf{R}=\left(\mathbf{r}_{1}, \mathbf{r}_{2}, \ldots, \mathbf{r}_{\mathrm{m}}\right)$, ahol $r_{i j}$ azt mutatja meg, hogy a j-edik tevékenység egységnyi szintű alkalmazásához mennyi szükséges az i-edik termékből.

- Elsődleges erőforrás-felhasználási együtthatók mátrixa: $D=\left(\mathbf{d}_{1}, \mathbf{d}_{2}, \ldots, \mathbf{d}_{\mathbf{m}}\right)$, ahol $d_{l j}$ azt mutatja meg, hogy a j-edik tevékenység egységnyi szintű alkalmazásához mennyi szükséges az l-edik elsődleges erőforrásból. A fent leírt folyamatokat az 1. ábra foglalja össze.

\section{1. ábra}

Egy termelővállalat múködésének magyarázata az LTM jelölőrendszer segítségével

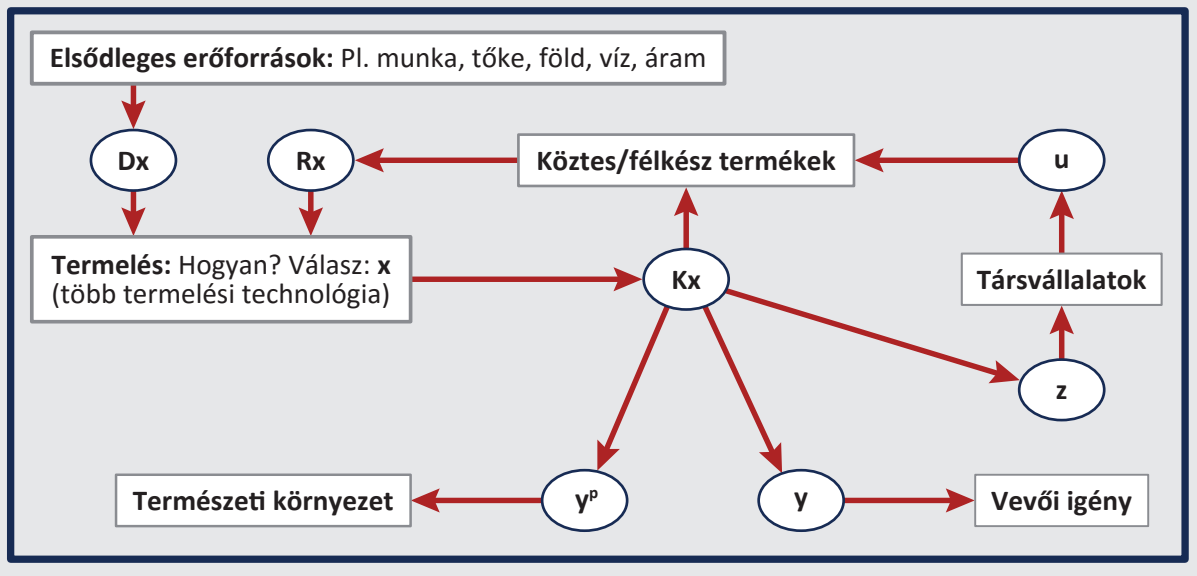

A lineáris tevékenységelemzés modelljében ez a három mátrix határozza meg a vállalat technológiai lehetőségeit. Elemeik pontos értékéről a múszaki menedzsment, illetve a mérnökök rendelkeznek információkkal, melynek összhangban kell állnia a vállalat számviteli rendszeréből kinyerhető adatokkal. Érdemes megjegyezni, hogy amennyiben a kibocsátási együtthatók mátrixának $i$-edik sorában egynél több pozitív elem van, akkor az i-edik terméket a vállalat többféle tevékenység révén is elő tudja állítani. Ilyenkor technológiai választékról beszélünk. A lineáris tevékenységelemzés feladata ez esetben a megfelelő technológiai kombináció kiválasztása is.

A lineáris tevékenységelemzési modell optimális feladatát a következő módon határozzuk meg: Legyen adott a vevői igény $\left(\mathbf{y} \in R_{+}^{n}\right)$. A nettó kibocsátást a Kx termékkibocsátás és az Rx termékfelhasználás különbsége adja, ami a kikötés szerint legalább a vevői igény $\mathbf{y}$ legyen. A vállalat termékmérlegét az alábbi egyenlet írja le: $(\mathbf{K}-\mathbf{R}) \mathbf{x} \geq \mathbf{y}$. Továbbá legyen adott az elsődleges erőforrások készlete $\underline{\mathbf{s}}$. A vállalat elsődleges erőforrás-felhasználását a Dx mátrixa írja le. Feltételezzük, hogy a vállalat kevesebb elsődleges erőforrást használ fel, mint a rendelkezésre álló mennyiség. Az erőforrásmérleg az alábbiak szerint alakul: $\mathbf{D x} \leq \mathbf{s}$. Ezen feltételek és az $\underline{\mathbf{x}}$ nem- 
negativitási feltétele mellett keressük azt a termelési szintet, amelynél a költség a legkisebb, vagy a bevétel a legnagyobb.

A feladat megoldásához a GAMS (General Algebraic Modeling System) szoftvert ajánljuk, mely kifejezetten az ilyen jellegü, $s$ a tanulmány további részében bemutatásra kerülő problémák megoldására fejlesztett, magas szintű programozási nyelvet bocsát a felhasználó rendelkezésére, $\mathrm{s}$ tantermi változata az internetről ingyenesen letölthető.

\section{Környezetkímélő stratégia, azaz a kék gazdaság elvét alkalmazó vállalat}

Az alábbi szakaszban egy olyan termelő vállalat működését mutatjuk be az LTM-módszertan keretei között, ahol a környezetvédelmi stratégia és jelen esetben a kék gazdaság elve hangsúlyos szerepet játszik a vállalat életében. Továbbá az LTM-modell primális és duális feladatának értelmezése támpontot ad a környezetvédelmi bírság és a belső elszámolóárak meghatározásához.

Egy vállalat által folytatható legtöbb termelőtevékenység a továbbfelhasználásra vagy a vevői igények kielégítésére alkalmas termékek mellett mellékterméket, a környezetre káros hulladékot vagy szennyezőanyagokat is kibocsát. George et al. (2015) szerint a piacgazdaság termelőfolyamatainak eredménye nem csupán a végtermék, hanem a nemkívánatos hulladék is, melynek megsemmisítése költséggel jár a vállalat számára. Ezt Dobos (2008) is megerősíti, és hozzáteszi, hogy a melléktermékek a termelésből nem zárhatók ki. Nehézség azonban, hogy ezeket a javakat gyakran nem tüntetik fel a termelési tervben. Hartung (2016) megjegyzi, hogy Dobos (2008) felismerése jelentős, mivel a gyártás során keletkezett melléktermékek hasznosítási lehetőségeinek feltárása lehetetlenné válhat, hiszen a vállalati tervező nem is tud azok létezéséról. Ugyanez a helyzet a hulladékok és a szennyezőanyagok esetében is. Szerepeltessük most ezeket is a jószáglistán ${ }^{3}$ ! Jelölje $\overline{\mathbf{y}}$ az egyes termékekből a környezetbe maximálisan kibocsátható, ám értékesítésre nem kerülő termékek mennyiségét! Az ebben szereplő nagyságokat mind a vállalat környezetvédelmi stratégiája, mind pedig a környezetvédelmi hatóság meghatározhatja. Dobos (2008) szerint ugyanakkor a jogszabályi kötelezettség önmagában nem feltétlenül jelent kényszerítő erőt az üzleti szféra számára, hiszen sok esetben a vállalatok inkább a könnyebben megfizethető bírságot választják (annak mértékétől függően).

A nullahulladék-elvre törekvés következményeként a vállalatnak nem csupán a vevők, hanem más vállalatok felé is nyitottnak kell lennie. A bevezető szakaszban említett kék gazdaság elvéből következik, hogy a félkész termékek, segédanyagok

\footnotetext{
3 „Egy technológia leírásának előfeltétele. Ebben ismertetik a vizsgált egység lehetséges termelési tevékenységeiben előfordulható javakat, azoknak egy teljes és átfedésektől mentes listáját" (Zalai 2012:72).
} 
és termelési szolgáltatások saját előálítása mellett vagy helyett ezek piacról történő beszerzését is lehetővé kell tenni. Így a házi előállítású félkész termékek mellett megjelennek a piacról beszerzett félkész termékek. Ezek mennyiségét az u vektor írja le. Ha a vállalat nem rendelkezik elegendő kapacitással, előfordul, hogy az i-edik termékre $0<y_{i} \cdot u_{i}$, ahol $y_{i}$ az i-edik termék iránt jelentkező vevői igény. Ez azt jelenti, hogy a vállalat a vevői igények egy részét nem saját termelése révén elégíti ki, hanem a piacon beszerzett készterméket bocsátja a vevő rendelkezésére. Általában azonban nem ez a helyzet, hanem $\forall i=1, \ldots, n: 0=y_{i} \cdot u_{i}$, azaz ha a vállalat valamilyen terméket a piacról vásárol, akkor ilyen terméket nem értékesít.

A környezetkímélő stratégia - csakúgy, mint a kék gazdaság elve - megköveteli a pazarló tevékenységek megszüntetését, ugyanakkor minden olyan melléktermék, hulladék, esetleg szennyezőanyag értékesítését is, melyek iránt fizetőképes piaci kereslet mutatkozik, vagy azok megsemmisítését más vállalat hatékonyabban képes elvégezni. Ennek a többi vállalat irányába fenntartott piaci nyitottságnak alapvető jelentősége van. Ha a vevői igények kielégítésén túl hatékony az erőforrás-gazdálkodás, akkor a vállalat természeti környezetre gyakorolt negatív hatása is csökken. Modellünkben a társvállalatok számára átadásra kerülő termékek mennyiségét a $\mathbf{z}$ vektor írja le. A piaci nyitottság jegyében többnyire olyan termékeket értékesít a vállalat, melyek iránt vevői igény nem mutatkozik $\left(z_{i} \cdot u_{i}=0\right)$, és ezeket a termékeket a piacon nem is vásárolja $\left(z_{i} \cdot u_{i}=0\right)$. A továbbiakban látni fogjuk, hogy ez a nyitottság teremt kapcsolatot a piaci árak és a vevői igények kielégítésére előállított termékek belső elszámolóára között.

Feltesszük, hogy a piaci nyitottságból adódó lehetőségek kihasználása során a vállalat az árakat nem képes befolyásolni, és az egyes termékeket a $\mathbf{p}^{m}$ vektor által leírt árakon szerezheti be, illetve a $\mathbf{p}^{\mathrm{e}}$ vektor által leírt árakon értékesítheti. Az általánosság érdekében feltesszük továbbá, hogy $\mathbf{p}^{\mathrm{e}} \leq \mathbf{p}^{\mathrm{m}}$. Mindezek alapján azt mondhatjuk, hogy a piaci nyitottságból adódó lehetőségek kihasználása során a vállalat $\mathbf{p}^{\mathrm{m}} \mathbf{u}-\mathbf{p}^{\mathrm{e}} \mathbf{z}$ mértékű veszteséget szenved el, melyet forgóeszközhitel felvétele révén finanszírozhat. A negatív veszteséget nyereségnek tekintjük, ami a forgóeszköz-finanszírozási igényt csökkenti. Ennek nagyságát felülről a vállalat finanszírozási feltételei által meghatározott $d_{e}$ érték korlátozza. $0<d_{e}$ esetén megengedett, hogy a piaci nyitottságból adódó lehetőségek kihasználása során a vállalat a korlát mértékéig veszteséget szenvedjen el, $0>d_{e}$ esetén nyereséget kell elérni, legalább a korlát által meghatározott mértékben. Ritkábban a $0=d_{e}$ egyensúlyi kritériumot is előírják a vállalat számára.

Jelölje $\overline{\mathbf{s}}$ a vállalat rendelkezésére álló elsődleges erőforrások meglévő mennyiségét! Ide tartoznak többnyire az állóeszközök, a gépek, a berendezések, a felszerelések és a dolgozók. Ezt az elsődleges erőforrásmennyiséget kell a vevői igények kielégítéséhez szükséges mértékben kiegészíteni. Az így beszerzésre kerülő többlet elsődleges erőforrások mennyiségét az s vektor írja le. Általánosságban nem igaz 
$s_{i} \cdot \bar{s}_{i}=0$ fennállása, inkább a meglévő elsődleges erőforrások készletét kell bővíteni. Feltesszük, hogy a vállalat az erőforráspiacon sem rendelkezik erőfölénnyel. Ekkor az elsődleges erőforrások árai a vállalat által nem befolyásolható konstansok, melyeket a q vektor tartalmaz. Mivel a vevői igények adottak és így a vállalat bevétele is adott, a nyereség csak a pótlólagosan beszerzendő elsődleges erőforrások költségének csökkentése révén növelhető. $\mathrm{E}$ költség nagyságát a qs skalárszorzat határozza meg.

A környezetkímélő stratégiát alkalmazó vállalat primális feladata, a módszertanban bemutatott LTM-feladattól eltérően, a következőképp alakul:

$$
\begin{array}{rlrl}
\mathbf{x}, \mathbf{z}, \mathbf{y}^{\mathbf{p}}, \mathbf{s}, \mathbf{u} & \geq 0 \\
(\mathbf{p}) & \mathbf{R} \mathbf{x}+\mathbf{y}+\mathbf{z}+\mathbf{y}^{\mathbf{p}} & =\mathbf{K} \mathbf{x}+\mathbf{u} \\
(\mathbf{w}) & \mathbf{D} \mathbf{x}-\mathbf{s} & \leq \overline{\mathbf{s}} \\
(v) & \mathbf{p}^{\mathrm{m}} \mathbf{u}-\mathbf{p}^{\mathrm{e}} \mathbf{z} & \leq d_{e} \\
\left(\mathbf{t}^{y}\right) & \mathbf{y}^{\mathbf{p}} & \leq \overline{\mathbf{y}} \\
& -\mathbf{q s} & \rightarrow \max
\end{array}
$$

Az egyes feltételek előtt zárójelben a hozzájuk tartozó duális változókat, más néven árnyékárakat ${ }^{4}$ tüntettük fel, melynek magyarázata később következik. A primális feladat (1) feltétele a változók előjelére tesz megkötéseket. A (2) feltétel a termékmérleg, ahol teljesül az egyensúlyi feltétel a termék és az erőforrások piacán. A (3) feltétel az elsődleges erőforrások mérlegegyenlete. A (4) feltétel a melléktermékek, hulladék- és szennyezőanyagok adásvétele során képződő, maximálisan megengedett veszteséget leíró egyenlet, ahol $d_{e}$ felvehet pozitív vagy nulla értéket is, de $0<d_{e}$ révén nyereség is előírható. $A(5)$ egyenlet az egyes termékekből a környezetbe maximálisan kibocsátható anyagok mennyiségét adja meg. Végül a (6) egyenlet a nyereséget maximalizáló célfüggvény.

A feladat megoldása során adottak: a vállalat termelési technológiáját leíró $\mathbf{K}, \mathbf{R}$ és $\mathbf{D}$ mátrixok; a vállalat elsődleges erőforrásokkal való ellátottsága $\overline{\boldsymbol{s}}$; a piaci nyitottságból adódó lehetőségek során maximálisan elérhető veszteség mértéke $d_{e}$; az elsődleges erőforrások piaci beszerzési árai q; a vállalat termékeinek beszerzési $\mathbf{p}^{\mathrm{m}}$, illetve értékesítési $\boldsymbol{p}^{\mathrm{e}}$ árai.

A feladat megoldása során kapjuk: az egyes tevékenységek alkalmazási szintjét $\mathbf{x}$, a pótlólagosan beszerzendő elsődleges erőforrások mennyiségét s, a piaci nyitott-

\footnotetext{
${ }^{4}$ „A lineáris optimális erőforrás-elosztási feladatok duális megoldásait árnyékáraknak (shadow price) szokás nevezni. Nem mások, mint a korlátozó feltételekben szereplő javak és erőforrások célfüggvényértékében kifejezett lehetőség költségei. Kifejezik, hogy a külső forrásokból rendelkezésre álló javak utolsó egysége mennyivel járul hozzá a célfüggvény értékéhez" (Zalai 2012:84).
} 
ság révén beszerzésre, illetve átadásra kerülő termékek mennyiségét $\mathbf{u}$ és $\mathbf{z}$, és az árnyékárakat $\mathbf{p}, \mathbf{w}, v$ és $\mathbf{t}^{\mathrm{y}}$.

Az egyes feltételekhez tartozó árnyékárak értelmezése:

(p) Az egyes termékek árnyékára megmutatja, hogy a vevői igény adott termékből történő egységnyi csökkenése esetén mennyivel csökkenne a pótlólagosan beszerzendő elsődleges erőforrások költsége: $p_{i}=\delta q s / \delta y_{i}$. Ha ez az érték kisebb, mint amennyit a vevő a szóban forgó termékért fizetni hajlandó, akkor a szóban forgó termék iránti vevői igény csak veszteséggel elégíthető ki.

(w) Az egyes elsődleges erőforrások árnyékára azt mutatja meg, hogy mennyivel csökkenne a pótlólagosan beszerzendő elsődleges erőforrások költsége, ha a vállalat a szóban forgó elsődleges erőforrásból egységnyivel többel rendelkezne, és így azt nem kellene beszerezni: $w_{i}=\delta$ qs $/ \delta \bar{s}_{i}$. Ha ez az érték nulla, akkor a dualitásnak megfelelően a szóban forgó elsődleges erőforrás pótlólagos beszerzése szükségtelen.

(v) A piaci nyitottság során képződő veszteség árnyékára megmutatja, hogy e veszteség egységnyi növekedése esetén mennyivel csökkenne a pótlólagosan beszerzendő elsődleges erőforrások költsége: $v=\delta$ qs $/ \delta d_{e}$.

( $\mathbf{t}_{\mathrm{i}}^{y}$ ) A kibocsátási korláthoz tartozó árnyékár azt mutatja meg, hogy mennyivel javulna a célfüggvényérték, azaz mennyivel nőne a vállalat profitja az i-edik termék környezetbe történő kibocsátásának egységnyivel történő növelése esetén. Ez az érték jó támpontként szolgál a kibocsátási korlátok túllépése miatt kiszabásra kerülő környezetvédelmi bírságok meghatározásához. Továbbá ez a meghatározási eljárás segít feloldani a szakirodalomban fellelt környezetvédelmi bírságokból fakadó kiszámíthatatlanságokat és eltéréseket.

A vállalat célja tehát adott y kibocsátás előállítása úgy, hogy a pótlólagosan beszerzésre kerülő elsődleges erőforrások költsége minimális legyen az $\overline{\mathbf{y}}$ vektor által előírt környezetvédelmi feltételek betartásával. $\overline{\mathbf{y}}_{i}=0$ esetén további feldolgozásra kerülő félkész termékről, melléktermékről vagy hulladékról van szó.

A környezetkímélő stratégiát alkalmazó vállalat duális feladatának megoldásaként kapjuk meg a belső elszámolóárakat ${ }^{5}$. A felíráshoz szükséges szimplex táblázatot a Függelék tartalmazza, melynek segítségével a duális feladat már könnyen felírható:

\footnotetext{
5 „A piaccal nem rendelkező közbenső termékek és elsődleges erőforrások árnyékára a lehetőségköltségeik által meghatározott vállalati belső elszámolóárak. Az árnyékárral sok szempontból rokon a belső elszámoló (accounting) ár elnevezés" (Zalai 2012:104).
} 


$$
\begin{aligned}
\mathbf{w}, v, \mathbf{t}^{y} & \geq 0 \\
\mathbf{p}(\mathbf{K}-\mathbf{R}) & =\mathbf{w D} \\
\mathbf{w} & \leq \mathbf{q} \\
\mathbf{p} & \leq v \mathbf{p}^{\mathrm{m}} \\
\mathbf{p} & \geq v \mathbf{p}^{\mathbf{e}} \\
\mathbf{p}+\mathbf{t}^{y} & \geq 0 \\
\mathbf{w} \overline{\mathbf{s}}+v \cdot d_{e}+\mathbf{t}^{\vee} \overline{\mathbf{y}}-\mathbf{p y} & \rightarrow \min
\end{aligned}
$$

Az alábbi probléma megoldásaként adódó belső elszámolóárak alkalmazása esetén fogja vállalatunk a minimális elsődleges erőforrásköltséget és így a maximális nyereséget biztosító $\underline{\mathbf{x}}$ tevékenység kombinációt választani.

A duális probléma duális változói, azaz a primális feladat változói itt a feltételek után állnak. Érdemes felhívni a figyelmet, hogy a primális feladatban szereplő egyenlőség-feltétel miatt a p változók előjelére semmiféle megkötést nem teszünk. Így bizonyos termékek belső elszámolóára negatív is lehet. A (11) és (12) feltétel szerint azonban ehhez az szükséges, hogy a szóban forgó termék adásvételi ára negatív legyen. Pontosan ez a helyzet a szennyezőanyagok esetében, hisz ezeket vállalatunk negatív áron vásárolhatja, azaz átvételükért az átadó fizet. Ebben az esetben vállalatunk végzi az átvett szennyezőanyag lerakását, feldolgozását vagy megsemmisítését. Azon szennyezőanyagok esetében, melyeknél ilyen tevékenységet vállalatunk nem végez, a megsemmisítendő szennyezőanyagokat más vállalatok részére átadhatja. Ebben az esetben azonban vállalatunk fizet azok átvételéért.

A duális feladat egyes feltételeinek értelmezése:

(8) Az elsődleges erőforrások belső elszámolóára és a termékek belső elszámolóára között fennálló összefüggést írja le.

(9) Az elsődleges erőforrások belső elszámolóára és piaci ára közti összefüggést írja le. Megjegyzendő, hogy ha a vállalat valamelyik elsődleges erőforrást vásárolja, akkor a feltétel egyenlőség formájában teljesül. Az egyes termékek belső elszámolóára ezek szerint az elsődleges erőforrások piaci árától függ, mely egybeesik a bevezetőben tárgyalt Lakatos - Karai (2015) kutatásának eredményével.

(10-11) Ha a vállalat más vállalat számára átad valamilyen mellékterméket vagy hulladékot, akkor annak belső elszámolóára egyenesen arányos az átadás során alkalmazott árral, ami negatív is lehet, pl. hulladékmegsemmisítés esetén. Ha átvesz valamilyen mellékterméket vagy hulladékot, a belső elszámolóár szintén az átvétel során alkalmazott árral lesz egyenesen arányos. 
(12) Ha $p_{i}<0$, akkor $t_{i}^{y}>0$. Ha tehát valamely terméknek negatív belső elszámolóára van, akkor $\bar{y}_{i}$ növekedésével a primális feladat célfüggvényértéke javulna azért, mert ebből a szennyezőanyagból a vállalat a környezeti kibocsátás $\bar{y}_{i}$ korlátjába ütközött!

Továbbá a dualitás miatt a duális és a primális feladat célfüggvényértéke megegyezik:

$$
\mathbf{w} \overline{\mathbf{s}}+v \cdot d_{e}+\mathbf{t}^{\mathrm{y}} \overline{\mathbf{y}}-\mathbf{p y}=-\mathbf{q} \mathbf{s}
$$

amiből

$$
\mathbf{w} \overline{\mathbf{s}}+\mathbf{q} \mathbf{s}+v \cdot d_{e}+\mathbf{t}^{\mathrm{y}} \overline{\mathbf{y}}=\mathbf{p y} .
$$

A (15) egyenlet jobb oldalán a vevői igények kielégítéséből adódó árbevétel áll. Ennek kell finanszírozni a bal oldalon álló költségelemeket. Ezek rendre az alábbiak:

- w⿳亠丷厂 a vállalatnál már meglévő elsődleges erőforrások finanszírozásának költsége,

- qs a pótlólagosan beszerzésre kerülő elsődleges erőforrások költsége,

$-v \cdot d_{e}$ a melléktermékek, hulladék- és környezetszennyező anyagok adásvétele során keletkező veszteség,

- $\mathbf{t}^{\mathrm{y}} \overline{\mathbf{y}}$ a káros anyagok környezetbe juttatásának korlátozásából származó veszteség.

Figyelembe véve a duális feladat (9) feltételéhez füzött megjegyzést, azt mondhatjuk, hogy mindezt belső elszámolóárakon számítva teszi a vállalat.

Az egyes termékek piaci árai és árnyékárai között fennálló összefüggések a duális feladatból adódnak. Tegyük fel egy pillanatra, hogy $\mathbf{p}^{\mathrm{m}}=\mathbf{p}^{\mathrm{e}}$ ! Ekkor az árnyékárak a piaci árakkal egyenesen arányosak, $s$ az arányossági tényező: $v$. Amennyiben $\mathbf{p}^{\mathbf{m}} \neq \mathbf{p}^{\mathrm{e}}$, akkor annak a terméknek az árnyékára, melyet a vállalat vásárol, annak beszerzési árával lesz egyenesen arányos, amelyet pedig melléktermékként vagy hulladékként értékesít, az eladási árával. Az arányossági tényező továbbra is $v$. Ha pedig $u_{i}+z_{i}=0$, tehát valamely terméket a vállalat nem vásárolja és csak a vevői igények kielégítése céljából értékesíti, ennek árnyékárára $v p_{i}^{m}<p_{i}<v p_{i}^{e}$ teljesül.

Kék gazdaságról abban az esetben beszélünk, ha az iménti feladatnak $\overline{\mathbf{y}}=0$ mellett megengedett megoldása van, hiszen a modellben megjelenítésre kerültek a kék gazdaság elvének legfontosabb szempontjai: a félkész, késztermékek termelésbe való integrálása; a melléktermékek, szennyezőanyagok vállalatok közti értékesítése (z) és (u); a termékmérlegbe szokásosan (pl. Zalai 2012) alkalmazott egyenlőtlenség helyett egyenlőség került; és a nullahulladék-elvű termelés $(\overline{\mathbf{y}}=0)$ betartása. Utóbbi azonban ilyen formában többnyire nem lehetséges, és a lineáris tevékenységelem- 
zési modell proporcionalitása következtében a vevői igények alacsonyabb szinten történő kielégítése, azaz y elemeinek csökkentése sem segít.

\section{Kvázi kék gazdaság típusú vállalat}

Az alábbi szakasz bemutatja a kék gazdaság elveit követni képtelen, de minimális környezetterhelésre törekvő kvázi kék gazdaság típusú vállalat működését. Látni fogjuk, hogy a nullahulladék-elv betartásához szükséges technológia hiányában a vállalat csak a környezet terhelése révén érhet el nyereséget.

Ahhoz, hogy a kék gazdaság elveit közelítő vállalat számára alkalmazható modellt kapjunk, fel kell adni a vállalat nyereségmaximalizáló tevékenységét, és helyébe a környezetterhelés minimalizálását kell célul tűzni. Ugyan a nullahulladék-elv szerinti kibocsátás többnyire nem tartható a vállalat számára, de a környezetből felhasznált elsődleges erőforrások és a környezetbe kibocsátott anyagok mennyisége csökkenthető. Ezt figyelembe véve a kvázi kék gazdaság típusú vállalat primális problémája az alábbi módon alakul:

$$
\begin{array}{rlrl}
\mathbf{x}, \mathbf{z}, \mathbf{y}^{\mathrm{p}}, \mathbf{s}, \mathbf{u} & \geq 0, \\
(\mathbf{p}) & \mathbf{R} \mathbf{x}+\mathbf{y}+\mathbf{z}+\mathbf{y}^{\mathbf{p}} & =\mathbf{K} \mathbf{x}+\mathbf{u} \\
(\mathbf{w}) & \mathbf{D} \mathbf{x}-\mathbf{s} & \leq \overline{\mathbf{s}} \\
(v) & \mathbf{p}^{\mathrm{m}} \mathbf{u}-\mathbf{p}^{\mathrm{e}} \mathbf{z} & \leq d_{e} \\
-\mathbf{r y} \mathbf{y}^{\mathbf{p}}-\mathbf{q} \mathbf{s} & \rightarrow \text { max. }
\end{array}
$$

A 3. szakaszban bemutatott primális feladatból egyrészt elhagytuk a szennyezőanyag-kibocsátást korlátozó feltételt, hiszen nulla-kibocsátás mellett a vállalat nem képes múködni. Másrészt megjelent a célfüggvényben a szennyezőanyag-kibocsátásból és elsődlegeserőforrás-felhasználásból adódó környezetterhelés minimalizálása.

A környezetet ugyanis egyrészt a szennyezőanyag kibocsátása, másrészt az elsődleges erőforrások (édesvízkészlet, más megújuló vagy nem megújuló természeti erőforrások) felhasználása terheli. Az elsőt az ry ${ }^{p}$ súlyozott összeg aggregálja, ahol $r_{i}$ az $i$-edik termék mint szennyezőanyag egységnyi mennyiségének környezetbe történő kibocsátásából adódó környezetterhelést számszerűsíti. Másrészt $q_{k}$ az előző szakasszal ellentétben most nem a $k$-adik elsődleges erőforrás beszerzési ára, hanem azt mutatja meg, hogy egységnyi $k$-adik típusú elsődleges erőforrás felhasználása mekkora környezetterhelést jelent. Ennek értelmében a 3. szakaszban feltüntetett nyereségmaximalizáló vállalati célkitúzést most egy környezetterhelést minimalizáló célfüggvény váltotta fel. $\mathrm{Ez}$, mivel $\mathbf{y}^{\mathfrak{p}} \geq 0$ megengedett, nem tekinthető teljes mértékben a kék gazdaság elvét követő vállalati működésnek, de ahhoz közelít. 
A (16-20) feladat szimplex táblázata alapján adódó duális probléma (a felíráshoz szükséges szimplex táblázatot a Függelék tartalmazza):

$$
\begin{aligned}
\mathbf{w}, v, \mathbf{t}^{y} & \geq 0, \\
\mathbf{p}(\mathbf{K}-\mathbf{R}) & \leq \mathbf{w D} \\
\mathbf{w} & \leq \mathbf{q} \\
\mathbf{p} & \leq v \mathbf{p}^{\mathbf{m}} \\
\mathbf{p} & \geq v \mathbf{p}^{\mathbf{e}} \\
\mathbf{p} & \leq-\mathbf{r} \\
\mathbf{w} \overline{\mathbf{s}}+v \cdot d_{e}-\mathbf{p y} & \rightarrow \min .
\end{aligned}
$$

A probléma megoldásaként adódó belső elszámolóárak esetén lesz racionális vállalatunk számára a minimális környezetterhelést eredményező $\underline{\mathbf{x}}$ tevékenység kombináció választása.

A (27) feltétel szerint, ha egy szennyezőanyagból van kibocsátás, akkor ennek belső elszámolóára megegyezik az egységnyi kibocsátásból adódó többlet-környezetterheléssel q meghatározása szerint. Hasonló a helyzet az elsődleges erőforrásokkal is. Ha a vállalat valamilyen elsődleges erőforrást beszerez, ennek belső elszámolóára is a felhasználásból adódó többlet-környezetterheléssel egyenlő. Továbbá, ha az i-edik szennyezőanyagból van kibocsátás, akkor $p_{i}=r_{i}$, és ha ennek a szennyezőanyagnak egy részét a vállalat más vállalat számára átadja, akkor $p_{i}=-r_{i}=v p_{i}^{e}$. Ezek szerint $p_{i}, p_{i}^{e}<0$ és $v=-r_{i} / p_{i}^{e}$, azaz $v$ a szennyezőanyag-kibocsátás révén történő környezetterhelés „árfolyama” gyanánt értelmezhető. Még érdekesebb eset, ha a vállalat más vállalattól vásárol szennyezőanyagot, s azt a környezetbe kibocsátja. Ez abban az esetben szolgálhatja a célfüggvény minimalizálását, illetve a környezetterhelés csökkentését, ha a szennyezőanyag átvétele magas $p_{i}^{m}$ áron történik, mert ekkor a $\mathbf{p}^{\mathbf{m}} \mathbf{u}-\mathbf{p}^{\mathrm{e}} \mathbf{z}$ különbség jelentős mértékben javul, ami további környezetterhelést csökkentő tevékenységek finanszírozását teszi lehetővé. Ekkor $p_{i}=-r_{i}=v p_{i}^{m}$, és $v=-r_{i} / p_{i}^{m}$ gyanánt értelmezhető, a környezetterhelés „árfolyamaként”. Nem fordul elő ilyen eset, ha az r vektor minden vállalat esetében azonos, de u ebben az esetben sem feltétlenül a zérusvektor, hisz vállalatunk rendelkezhet olyan technológiával, mely a más vállalatnál keletkező hulladékot a fogyasztói igények kielégítésére alkalmas termékké alakítja, vagy szennyezőanyag-mentesítés során hasznosítja. Ezek szerint a vállalatnál alkalmazott belső elszámolóárak alapja a természeti erőforrások felhasználásából, illetve a szennyezőanyag-kibocsátásból adódó környezetterhelés.

A dualitásból következik továbbá a primális és a duális feladat célfüggvényértékének egyenlősége: 


$$
\mathbf{w} \overline{\mathbf{s}}+v \cdot d_{e}-\mathbf{p y}=-\mathbf{r y} \mathbf{p}^{\mathbf{p}}-\mathbf{q s},
$$

amiből

$$
\mathbf{p y}-\mathbf{w} \overline{\mathbf{s}}-v \cdot d_{e}=\mathbf{r y}{ }^{\mathbf{p}}+\mathbf{q s} .
$$

A (29) egyenlet bal oldalán a vevői igények kielégítéséből adódó árbevétel áll, csökkentve a költségelemekkel. Ez finanszírozza a jobb oldalon álló környezetterhelést. Megjegyzések

1. A vállalatnál nem azért képződik nyereség (ha egyáltalán képződik), mert célja a nyereségmaximalizálás, hanem azért, hogy minimális környezetterheléssel legyen képes a vevői igények kielégítésére.

2. A pótlólagosan beszerzett elsődleges erőforrások költségét környezetterhelésként vettük számba.

3. Ha a vállalat zéró környezetterhelés mellett tudja a vevői igényeket kielégíteni (optimális megoldásnál a primális feladat célfüggvényértéke nulla), akkor nem ér el nyereséget.

A 3. pont a tanulmány eddigi fő eredménye. Eszerint egy vállalat csakis környezetterhelés révén válhat nyereségessé. Így viszont a kék gazdaság vállalatai nem lehetnek nyereségesek. Eredményünk hasonlít a földjáradék elméletéhez, mely szerint a természeti erőforrások (föld) szúkössége tartós gazdasági profitot eredményez ( $B a$ rancsuk 2012:279). Ez az a járadék, amit a természeti erőforrás birtokosa sajátít el.

\section{Következtetések és további kutatási irányok}

Tanulmányunkban a természeti környezetbe ágyazottságra tekintettel lévő vállalatok optimális erőforrás-allokációját modelleztük a lineáris tevékenységelemzés módszerének segítségével. A harmadik szakaszban a kék gazdaság elvét betartó vállalat feltételeit vettük sorra, és építettük be a lineáris tevékenységelemzés modelljébe. Az LTM-modellben definiálásra került egy nyereségmaximalizáló célkitǔzés, $\overline{\mathbf{y}}=0$ zérus szennyezőanyag-kibocsátás mellett. A duális feladatban megmutattuk, hogy a belső elszámolóárak pozitiv és negatív értéket is egyaránt felvehetnek, ami lehetővé teszi a szennyezőanyagok átadását és átvételét. Megmutattuk továbbá, hogy a kibocsátási korlátokhoz tartozó árnyékárak a hatékony környezetvédelmi bírságolás alapjául szolgálhatnak. Ehhez természetesen ismerni kell a vállalat termelési technológiáját leíró $\mathbf{K}, \mathbf{R}, \mathbf{D}$ mátrixokat és a vállalat elsődleges erőforrás ellátottságát leíró $\overline{\mathbf{s}}$ vektort.

A negyedik szakaszban a szigorú nullahulladék elv betartásának lehetetlensége esetén, meghatároztunk egy környezetterhelést minimalizáló, kvázi kék gazdaság típusú 
vállalati modellt LTM-keretek közt. Megjelent a célfüggvényben az elsődleges erőforrások felhasználásból és a szennyezőanyag-kibocsátásból adódó környezetterhelés minimalizálása. A duális feladatból adódik a tanulmány fő eredménye, miszerint csak környezetterhelés révén válhat nyereségessé egy vállalat, következésképpen a kék gazdaság típusú vállalatok nem lehetnek nyereségesek. Továbbá a vállalatnál alkalmazott belső elszámolóárak alapja a természeti erőforrások felhasználásából és a szennyezőanyagok kibocsátásából adódó környezetterhelés.

További kutatási irányként körvonalazódik a környezetterhelést aggregáló függvény meghatározása, hiszen a környezetterhelés szintjének $\mathbf{r y}^{\mathfrak{p}}+\mathbf{q s}$ lineáris célfüggvény révén történő meghatározásával szemben az a kifogás tehető, hogy gyakran nem áll fenn egyenes arányosság bizonyos szennyezőanyagok kibocsátása és az ebből adódó környezetterhelés között. Bár az eddigi szakirodalmi hivatkozások lineáris kapcsolatot feltételeznek a szennyezőanyag-kibocsátás és annak hatása között (Wenzel et al. 1997; Potting - Hauschild 1997; Brink et al. 2001; Abdullah 2014), célszerü lenne feltételezni, hogy bizonyos esetekben a helyzet ennél rosszabb: a szennyezőanyag-kibocsátás $\lambda$-szorosára növelése esetén az ebből adódó környezetterhelés rendszerint több mint $\lambda$-szorosan nő. A probléma modellezése érdekében fel kell tehát adni a lineáris célfüggvényt, s helyette például az alábbi konvex függvényt kell alkalmazni:

$$
f\left(y^{p}, s\right)=\sum_{i=1}^{n} r_{i}\left(y_{i}^{p}\right)^{\alpha_{i}}+\sum_{k=1}^{l} q_{i}\left(s_{k}\right)^{\beta_{k}}, \text { ahol } \alpha_{i}, \beta_{k} \geq 1 .
$$

A modell feltételei egy konvex poliédert határoznak meg, s mivel a célfüggvény konvex, a lokális megoldás egyúttal globális is lehet, ennek köszönhetően súlyosabb matematikai problémákra nem számítunk.

Kuti (2014) szerint a fenntarthatóság számos kockázatot és lehetőséget jelent a vállalatok számára. Kockázatként jelentkezik a törvényszegési bírság, a hulladékgazdálkodás, a szúkös erőforrásokért folyó, növekvő verseny és ezek emelkedő költségei. Lehetőségként merül fel a működési hatékonyság javulása, a jobb kockázatkezelés és a felelős termékekből/szolgáltatásokból származó bevétel. Érdemes megvizsgálni a Kuti (2014) által felvetett kockázatok és lehetőségek hatását a termelővállalatokra, azonban ehhez egy sztochasztikus modellre kell áttérni. 


\section{Felhasznált irodalom}

Abdullah, L. (2014): Linear Relationship between $\mathrm{CO}_{2}$ Emissions and Economic Variables: Evidence from a Developed Country and a Developing Country. Journal of Sustainable Development, Vol. 8, Issue 2: 66-72.

Barancsuk János (2012): Mikrogazdaságtan. 2. átdolgozott kiadás, Pécs, Pécsi Tudományegyetem, Közgazdaságtudományi Kar.

Benyus, J. M. (1997): Biomimicry: Innovation Inspired by Nature. New York, Harper Collins Publishers Inc.

Bessenyei István (2016): Vállalati stratégia a lineáris tevékenységelemzés modelljében. International Journal of Engineering and Management Sciences, 1: 1-14. https://doi. org/10.21791/IJEMS.2016.1.9.

Bocken, N.M.P. - Short, S.W. - Rana, P. - Evans, S. (2014): A Literature and Practice Review to Develop Sustainable Business Model Archetypes. Journal of Cleaner Production, Vol. 65: 42-56. https://doi.org/10.1016/j.jclepro.2013.11.039.

Brink, C. - van lerland, E. - Hordijk, L - Kroeze, C. (2001): Cost-Effective Emission Abatement in Europe. Optimizing Nitrogen Management in Food and Energy Production and Environmental Protection. Contributed papers from the 2nd International Nitrogen Conference 14-18 october 2001, Potomac, Maryland, USA. In: The Scientific World (2001) 1(S2): 814-821. https://doi.org/10.1100/tsw.2001.295.

Ding, H. - Zhao, Q - An, Z. - Xu, J. - Liu, Q. (2015): Pricing Strategy of Environmental Sustainable Supply Chain with Internalizing Externalities. International Journal Production Economics, 170: 563-575. https://doi.org/10.1016/j.ijpe.2015.05.016.

Dobos István (2008): Visszutas logisztika és termeléstervezés. Szigma, évf. 39, 3-4: 139-167.

Esty, D. - Porter, M. (1988): Industrial Ecology and Competitiveness: Strategic Implications for the Firm. Journal of Industrial Ecology Vol. 2, No. 1: 35-43. https://doi.org/10.1162/ jiec.1998.2.1.35.

Gao, L. - Zhao, X. (2015): Determining Intra-company Transferpricing for Multinational Corporations. International Journal Production Economics, Vol. 168: 340-350. https:// doi.org/10.1016/j.ijpe.2015.07.006.

Genovese, A. - Acquaye, A. A. - Figueroa, A. - Koh, A. C. L. (2017): Sustainable Supply Chain Management and the Transition towards a Circular Economy: Evidence and some Applications. Omega, Vol. 66, Part B, pp. 344-357. https://doi.org/10.1016/j. omega.2015.05.015. 
George, D.A.R. - Lin, B.C. - Chen, Y. (2015): A Circular Economy Model of Economic Growth. Environmental Modeling and Software, Vol. 73: 60-63. https://doi.org/10.1016/j. envsoft.2015.06.014.

Ghisellinia, P. - Cialanib, C. - Ulgiatic S. (2016): A Review on Circular Economy: the Expected Transition to a Balanced Interplay of Environmental and Economic Systems. Journal of Cleaner Production, Vol. 114: 11-32. https://doi.org/10.1016/j.jclepro.2015.09.007.

Hartung Katalin (2016): Természeti környezetbe ágyazott vállalatok, és termelésük módszertani szakirodalmának áttekintése. Szigma, szám 1-2: 63-77.

Jaehn, F. (2016): Sustainable Operations. European Journal of Operational Research, Vol. 253: 243-264. https://doi.org/10.1016/j.ejor.2016.02.046.

Karpoff, J.M. - Lott, J.R. - Rankine, G. (1998): Environmental Violations, Legal Penalties, and Reputation Costs. John M. Olin Law and Economics Working Paper No. 71., University of Chicago.

Khalili, N.R. - Duecker, S. - Ashton, W. - Chavez, F. (2015): From Cleaner Production to Sustainable Development: the Role of Academia. Journal of Cleaner Production, 96: 30-43. https://doi.org/10.1016/j.jclepro.2014.01.099.

Klemes, J. J. - Varbanov, P. S. - Huisingh, D. (2012): Recent Cleaner Production Advances in Process Monitoring and Optimization. Journal of Cleaner Production, 34: 1-8. https://doi. org/10.1016/j.jclepro.2012.04.026.

Kuti Mónika (2014): A fenntarthatóság és a pénzügyek integrálhatóságának kihívásai. Hitelintézeti Szemle, 13 évf. 2: 164-173.

Lakatos Mária - Karai Éva (2015): Venni vagy eladni? Magyar szén-dioxid-kvóta-kereskedelem - tanulóévek. Pénzügyi Szemle, 3: 333-348.

Li, R.H.-Su, C.H. (2012): Evaluation of the Circular Economy Development Level of Chinese Chemical Enterprises. Procedia Environmental Sciences, 13: 1595-1601. https://doi. org/10.1016/j.proenv.2012.01.151.

Munck, L. (2016): Sustainable Grain Production and Utilization. Encyclopedia of Food Grains (2ndedition), Vol. 4: 144-153. https://doi.org/10.1016/B978-0-12-394437-5.00204-7.

OECD (2009): Determination and Application of Administrative Fines for Environmental Offences: Guidance for Environmental Enforcement Authorities in EECCA Countries. https:// www.oecd.org/env/outreach/42356640.pdf. Letöltés ideje: 2016. október 28.

Pauli, G. (1997): Zero Emissions: The Ultimate Goal of Cleaner Production. Journal of Cleaner Production, Vol. 5, 1-2: 109-113. https://doi.org/10.1016/S0959-6526(97)00013-9. 
Pauli, G. (1998): Technology Forecasting and Assessment: The Case of Zero Emissions. Technological Forecasting and Social Change, Vol. 58, Issue 1-2: 53-68. https://doi. org/10.1016/S0040-1625(97)00055-3.

Pauli, G. (2010): A Kék Gazdaság. PTE KTK Kiadó.

Potting, J. - Hauschild, M. (1997): Predicted Environmental Impact and Expected Occurrence of Actual Environmental Impact part 1: The Linear Nature of Environmental Impact from Emissions in Life-cycle Assessment. The International Journal of Life Cycle Assessment, Vol. 2, Issue 3: 171-174. https://doi.org/10.1007/BF02978815.

Schlemminger, H. - Martens, C.P. (2004): German Environmental Law for Practitioners. 2nd ed., CN The Hague, Kluwer Law International.

Wenzel, H. - Hauschild, M. - Alting, L. (1997): Environmental Assessment of Products. Volume 1: Methodology, Tools and Case Studies in Product Development. USA, Kluwer Academic Publishers.

Zalai Ernő (2012): Matematikai közgazdaságtan II. - Többszektoros modellek és makrogazdasági elemzések. Akadémiai Kiadó, Budapest. 


\section{Függelék}

A környezetterhelés minimalizálására törekvő vállalat duális feladatának felírásához szükséges szimplex táblázat:

\begin{tabular}{c|ccccc|cc} 
& $\mathbf{x}$ & $\mathbf{s}$ & $\mathbf{u}$ & $\mathbf{z}$ & $\mathbf{y}^{\mathbf{p}}$ & & \\
\hline $\mathbf{p}$ & $-(\mathbf{K}-\mathbf{R})$ & 0 & $-\mathbf{E}$ & $\mathbf{E}$ & $\mathbf{E}$ & $=$ & $-\mathbf{y}$ \\
$\mathbf{w}$ & $\mathbf{D}$ & $-\mathbf{E}$ & 0 & 0 & 0 & $\leq$ & $\overline{\mathbf{s}}$ \\
$v$ & 0 & 0 & $\mathbf{p}^{\mathrm{m}}$ & $-\mathbf{p}^{\mathrm{e}}$ & 0 & $\leq$ & $d_{e}$ \\
$\mathbf{t}^{y}$ & 0 & 0 & 0 & 0 & $\mathbf{E}$ & $\leq$ & $\overline{\mathbf{y}}$ \\
& $\geq$ & $\geq$ & $\geq$ & $\geq$ & $\geq$ & & \\
\hline & 0 & $-\mathbf{q}$ & 0 & 0 & 0 & &
\end{tabular}

A kvázi kék gazdaság típusú vállalat duális feladatának felírásához szükséges szimplex táblázat:

\begin{tabular}{c|ccccc|cc} 
& $\mathbf{x}$ & $\mathbf{s}$ & $\mathbf{u}$ & $\mathbf{z}$ & $\mathbf{y}^{\mathbf{p}}$ & & \\
\hline $\mathbf{p}$ & $-(\mathbf{K}-\mathbf{R})$ & 0 & $-\mathbf{E}$ & $\mathbf{E}$ & $\mathbf{E}$ & $=$ & $-\mathbf{y}$ \\
$\mathbf{w}$ & $\mathbf{D}$ & $-\mathbf{E}$ & 0 & 0 & 0 & $\leq$ & $\overline{\mathbf{s}}$ \\
$v$ & 0 & 0 & $\mathbf{p}^{\mathrm{m}}$ & $-\mathbf{p}^{\mathbf{e}}$ & 0 & $\leq$ & $\mathbf{d}_{\mathrm{e}}$ \\
& $\geq$ & $\geq$ & $\geq$ & $\geq$ & $\geq$ & &
\end{tabular}

